\title{
The Effects of Quercetin with or Without Hyperthermia on HeLa Cells
}

\author{
Ceren Yıldız Eren ${ }^{1}$, M.D., Canan Vejselova Sezer ${ }^{2}$, PhD., Hulusi Goktug Gurer ${ }^{1}$, M.D., \\ Ozlem Ozgur Gursoy ${ }^{1}$, M.D. \\ ${ }^{1}$ Eskisehir Acibadem Hospital, Obstetrics and Gynecology Clinic \\ ${ }^{2}$ Eskisehir Technical University, Faculty of Science, Department of Biology \\ *Corresponding Author: Ozlem Ozgur Gursoy, Eskisehir Acibadem Hospital, Obstetrics and \\ Gynecology Clinic, Eskisehir, Turkey.
}

\begin{abstract}
Aim: The aim of this study was to further elucidate the quercetin- induced anticancer effects on the Human cervix adenocarcinoma HeLa cell line derived from cervical cancer cells.

Materials and Methods: HeLa cells were exposed to different concentrations of quercetin and apoptotic changes were recorded with confocal microscopy and transmission electron microscopy. Also Annexin-V analysis and ROS measurement were analyzed. Cytotoxicity was tested on quercetin exposed HeLa cells with hyperthermia.
\end{abstract}

Results: Quercetin have good anticancerous activities in vitro by inhibiting the proliferation of HeLa cells. The recorded $I C_{50}$ value of quercetin was $114 \mu \mathrm{M}$ for 48 hours. Hyperthermia didnot influence significantly on the growth inhibition of HeLa cells applied with quercetin.

Conclusion: Our results demonstrated that quercetin could induce apoptosis in a time and concentrationdependent manner in HeLa cervical cancer cells.

Keywords: quarcetin; HeLa cells; hyperthermia

\section{INTRODUCTION}

Cancer is the leading cause of death in the World (1). Cervical cancer is the fourth most frequently occurring malignancy in women worldwide (2). Approximately $85 \%$ of deaths from cervical cancer occur in underdeveloped or developing countries, probably due to inadequate screening programs. Infection with high-risk oncogenic human papillomavirus (HPV) is defined as the main cause of the disease (3). The viral proteins E6 and E7 play the critical role by inducing proliferation and malignant transformation of cells. Both $\mathrm{pRB}$ and p53 proteins have the crucial role in cell cycle control, and found to be mutated in many human cancers (4). p53 causes apoptosis in cells with unscheduled S-phase; however, E6 protein counteracts this function. Binding of E7 to $\mathrm{pRB}$ ends up with the expression of proteins necessary for DNA replication. Therefore, the research of antitumour drugs based on the principal of reactivation of $\mathrm{p} 53$ in wild-type $\mathrm{p} 53$ retaining tumor cells (5).

Surgery, chemotherapy and radiotherapy are the treatment modalities of cervical cancer but surgical choice is convenient only to patients with early stage and fertile-age women . Radiotherapy and chemotherapy are proved to be effective but have significant toxicity to normal cells because they are not specific to cancer cells $(6,7)$.

Various natural phytochemicals in plants have proved to have selective cytotoxicity to human cancer cells with minimal toxicity to normal cells $(8,9)$. Phytochemicals like caretonoids, flavonoids, isoflavones and terpenes, represent an alternative method for developing new therapeutics. Although complete anticancer mechanisms of them have not been clearly defined, flavonoids were showed to have diverse range of biological activities including inhibition of phosphoinositide-3-kinase, reactive oxygen species (ROS) generation, DNA damage, cell cycle arrest and apoptosis, as well as p53 restoration (10). Quercetin is one of the flavonoids abundantly found in fruits, vegetables, red wine, tea and olive oil (11). It was proven to that it inhibited the cell proliferation through cell cycle arrest, apoptosis and DNA fragmentation, together with an 
increase of the total p53 protein and p53 phosphorylation $(12,13)$.

In the light of promising effects of flavonoids, the aim of this study was to further elucidate the quercetin - induced anticancer effects on the HeLa cell line derived from cervical cancer cells.

\section{Materials ANd Methods}

Human cervix adenocarcinoma HeLa $\left(\mathrm{ATCC}^{\circledR} \mathrm{CCL}-2^{\mathrm{TM}}\right.$ ) cells were obtained from the American Type Culture Collection (Manassas, USA). Quercetin (Pure) was purchased from Akcan Kimya (Turkey), fetal bovine serum, penicillin/streptomycin, dimethyl sulfoxide and 3-(4,5-dimethylthiazol-2-yl)-2,5 diphenyl-2Htetrazolium bromide (MTT) were obtained from Sigma-Aldrich (St. Louis, USA). Eagle's Minimum Essential Medium (EMEM) was from Sigma-Aldrich (St. Louis, USA). Oxidative Stress and Annexin-V Kits were from (Merck, Millipore, USA).

\section{Cell culture}

HeLa cells were grown in EMEM medium containing penicillin-streptomycin (100 units $/ \mathrm{mL}-100 \mu \mathrm{g} / \mathrm{mL}$ ) and fetal bovine serum $(10 \%)$ at $37^{\circ} \mathrm{C}$ and $5 \% \mathrm{CO}_{2}$ in humidified incubator. Cell plates with confluency of $85 \%$ were used as test cell lines.

\section{MTT Colorimetric Assay}

Stock solution of quercetin (in distilled water) was prepared and further diluted in fresh complete culture medium. Quercetin concentrations ranging from of 6,25-200 $\mu \mathrm{M}$ were applied to test cell $\left(5 \times 10^{3} /\right.$ well $)$ and incubated for 24 and 48 hours at $37^{\circ} \mathrm{C}$ and $5 \%$ $\mathrm{CO}_{2}$ in humidified incubator. After the incubation $20 \mu \mathrm{L}$ of MTT solution $(5 \mathrm{mg} / \mathrm{mL})$ was added to each well then plates were incubated for 4 hours in the same incubator conditions. At the end of this incubation formazan crystals were dissolved with adding DMSO $(200 \mu \mathrm{L} /$ well $)$ and plates were read on an ELISA reader (HTX Synergy, BioTek, USA) at a wavelength of $564 \mathrm{~nm}(\mathrm{n}=3)$. Viability percentages were calculated from the obtained absorbances with the accordance of untreated cell absorbances. $\mathrm{IC}_{50}$ values were calculated from the viability percentages and used for other experimentations.

\section{Cytotoxicity Test with Hyperthermia}

The test was realized in order to test the influence of temperature on the viability of cells exposed to quercetin. For this manner, to imitate the Hyperthermic Intraperitoneal Chemotherapy
(HIPEC) clinical conditions HeLa cells were incubated at hyperthermia with different concentrations $(6,25-200 \mu \mathrm{M})$ of quercetin for 1 hour. After the incubation period media were aspirated and standard culture media for each cell line were added to the plates $(200 \mu \mathrm{L} /$ well $)$ and plates were further incubated at $37^{\circ} \mathrm{C}$ and $5 \% \mathrm{CO}_{2}$ in humidified incubator for 24 and 48 hours. At the end of incubation periods MTT procedure was applied and viability percentages were calculated and recorded.

\section{Confocal Microscopy}

The morphological changes caused by quercetin on HeLa cells were imaged under a Leica ICSSP5 II confocal microscope supplemented with an adequate software (Leica Confocal Software Version 2.00, Leica, Germany). Briefly, HeLa cells were plated on cover slips $\left(5 \times 10^{5}\right.$ cells/well) and incubated with $\mathrm{IC}_{50}$ concentrations of quercetin at $37{ }^{\circ} \mathrm{C}$ in a incubator for 48 hours. Untreated cells were used as control group. After the incubation all cell samples were fixed in $2 \%$ glutaraldehyde for 10 minutes at room temperature and washed in PBS (1x). Washed cell samples were stained in Alexa fluor-488 phalloidin and acridine orange then imaged under confocal microscope.

\section{Transmission Electron Microscopy}

In this manner, HeLa cells were treated with $\mathrm{IC}_{50}$ concentration of quercetin 48 hours. Untreated and quercetin treated HeLa cells were fixed in glutaraldehyde $(2.0 \%)$ and post-fixed in osmium tetroxide $(2 \%)$. Then, samples were dehydrated in ethanol and embedded in Epon 812 epoxy. After their polymerization for 48 hours, the obtained blocks were thin sectioned $(100 \mathrm{~nm})$ in ultramicrotome (Leica EMUC6). The thin sections were taken in copper grids and stained with uranyl acetate and lead citrate and imaged under a TEM (FEI Tecnai BioTWIN).

\section{Annexin-V Analysis}

Cell death mode of quercetin treated HeLa cells was analyzed by using annexin $\mathrm{V}$ technique by a flow cytometer. Fort his manner, cells were seeded $\left(5 \times 10^{5}\right.$ cells/well $)$ in six-well culture plates and exposed to $\mathrm{IC}_{50}$ concentration of quercetin for 48 hours at $37{ }^{\circ} \mathrm{C}$. Untreated cells were used as control cells. At the end of incubation period, cells were trypsinized and washed with PBS. Washed cells were treated with $100 \mu \mathrm{L}$ of annexin-V reagent and for 15 minutes at dark at room temperature (Muse ${ }^{\circledR}$ Annexin-V and Dead Cell Assay Kit). All cell samples were read on Muse ${ }^{\mathrm{TM}}$ Cell Analyzer (Merck, Millipore, Hayward, California, USA). 


\section{ROS Measurement}

For analysis of reactive oxygen species HeLa cells after the incubation with quercetin for 48 hours were harvested and suspensed in $1 \mathrm{X}$ Assay Buffer. Cell suspensions were incubated with Muse ${ }^{\circledR}$ Oxidative Stress working solution at $37^{\circ} \mathrm{C}$ for 30 minutes according to the user manuals of Oxidative Stress Kit and Cell Cycle Kit (Merck, Millipore, USA). At the end of RESULTS incubation all samples were analysed by using Muse ${ }^{\mathrm{TM}}$ Cell Analyzer (Merck, Millipore, Hayward, California, USA).

\section{Statistical Analysis}

The statistical evaluations of test results were done by using one way variance analysis for multiple comparisons of GraphPad Prism 6.0 for Windows.

\section{MTT Findings}

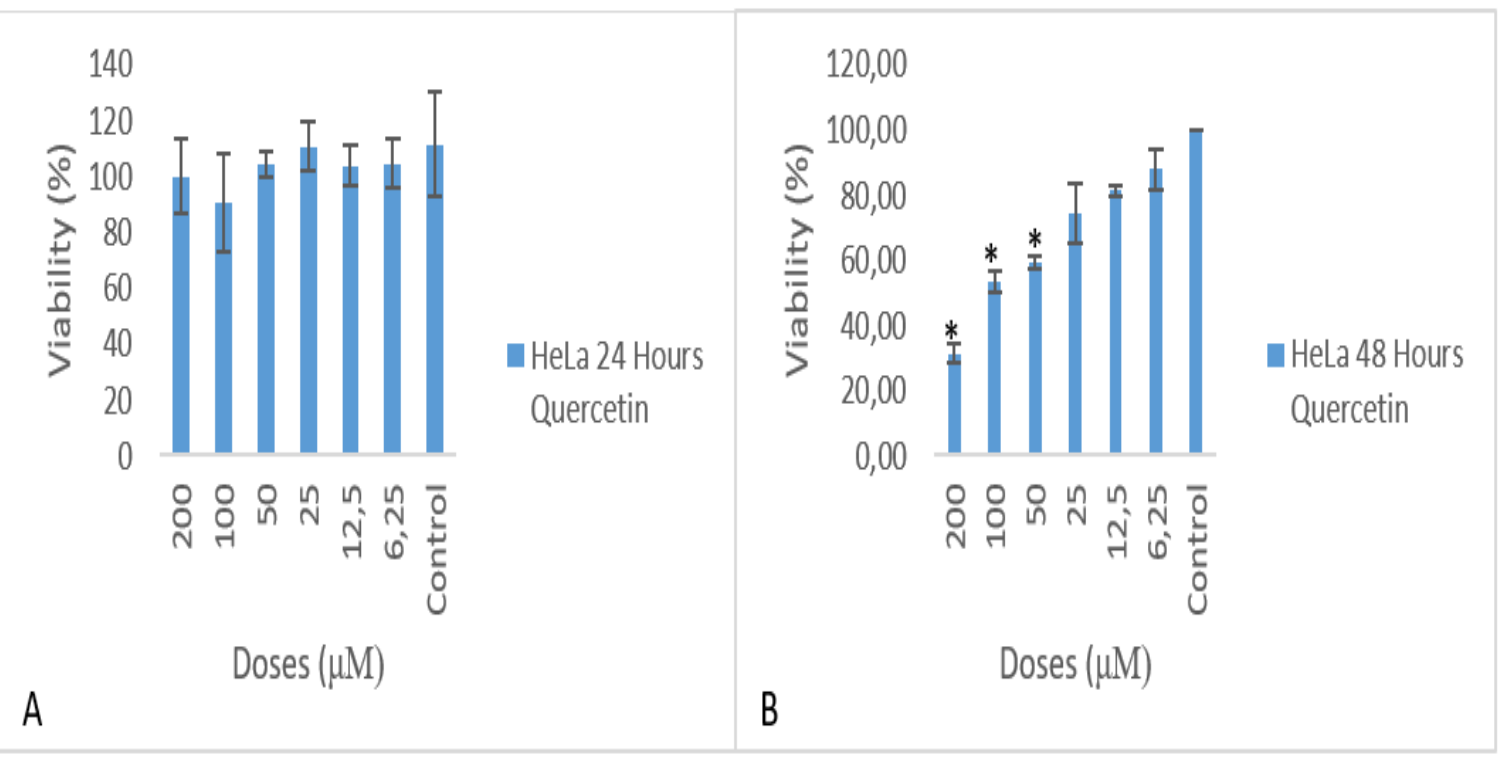

Figure1. Viability percentages of HeLa cells after exposure to different quercetin concentrations for 24 hours (A) and 48 hours $(B)$ at standard culture conditions. (*: $p<0,5)$ IC $C_{50}$ value of quercetin for 48 hours was detected to be $114 \mu \mathrm{M}$.

Figure 1 shows viability percentages of HeLa cells after exposure to different quercetin concentrations.

Cytotoxicity findings obtained by MTT assay showed that quercetin have dose and timedependent antiproliferative activity on HeLa cells. The $\mathrm{IC}_{50}$ value of quercetin was detected to be $114 \mu \mathrm{M}$ for 48 hours on HeLa cells. The highest inhibition was recorded at the highest applied concentration $(200 \mu \mathrm{M})$ of quercetin after 48 hours of incubation. Significant growth inhibition was detected at 200, 100, 50 and 25 $\mu \mathrm{M}$ concentrations of quercetin after 48 hours of application. Our MTT finding imply to the cytotoxic and antiproliferative activities of quercetin on HeLa cells in dose and timedependent manner.

\section{Hyperthermia Findings}

Figure 2 shows viability percentages of HeLa cells after exposure to different concentrations of quercetin.
In order to detect the effect of temperature and applied quercetin together different concentrations of quercetin were applied to HeLa cells at different temperatures following that MTT assay was performed to record the cytotoxicity. From hyperthermia test results it was seen that temperature does not influence significantly on the growth inhibition of HeLa cells applied with quercetin. No effect of temperature was recorded for $\mathrm{HeLa}$ cells at $38^{\circ} \mathrm{C}$ degree but viability percentages found to be decreased at $40^{\circ} \mathrm{C}$ to $80 \%$ after incubation for 24 hours. Similarly at $42^{\circ} \mathrm{C}$ the viability of HeLa cells were found to be decreased to $79 \%$ and $80 \%$ for 24 and 48 hours, respectively. The highest decrease of viability was found at $44^{\circ} \mathrm{C}$ at $200 \mu \mathrm{M}$ for 24 ( to $59 \%$ ) and 48 (to $47 \%$ ) hours of exposure to quercetin concentrations. These finding underline the effect of quercetin on HeLa cells in dose and time dependent manner as well as the slight role of temperature on these effects of quercetin at the applied higher concentrations. 


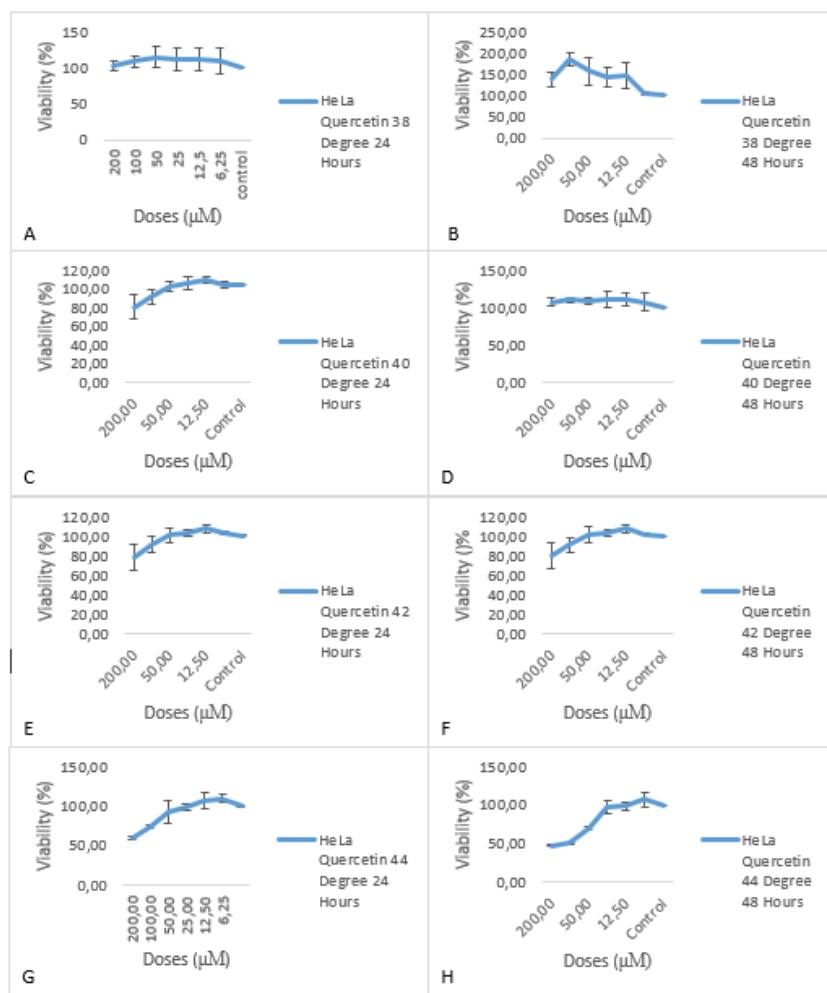

Figure2. Viability percentages of HeLa cells after exposure to different concentrations of quercetin for 24 and 48 hours at different incubation temperatures $\left(A-38^{\circ} \mathrm{C}, 24 \mathrm{Hours}\right.$ and $B-38^{\circ} \mathrm{C}, 48 \mathrm{Hours} ; \mathrm{C}-40^{\circ} \mathrm{C}, 24 \mathrm{Hours}$ and $D-40^{\circ} \mathrm{C}, 48$ Hours; $E-42^{\circ} \mathrm{C}, 24$ Hours and $\mathrm{F}-42^{\circ} \mathrm{C}, 48$ Hours; $G-44^{\circ} \mathrm{C}, 24$ Hours and $\mathrm{H}-44^{\circ} \mathrm{C}, 48$ Hours).

\section{Confocal Microscopy Findings}
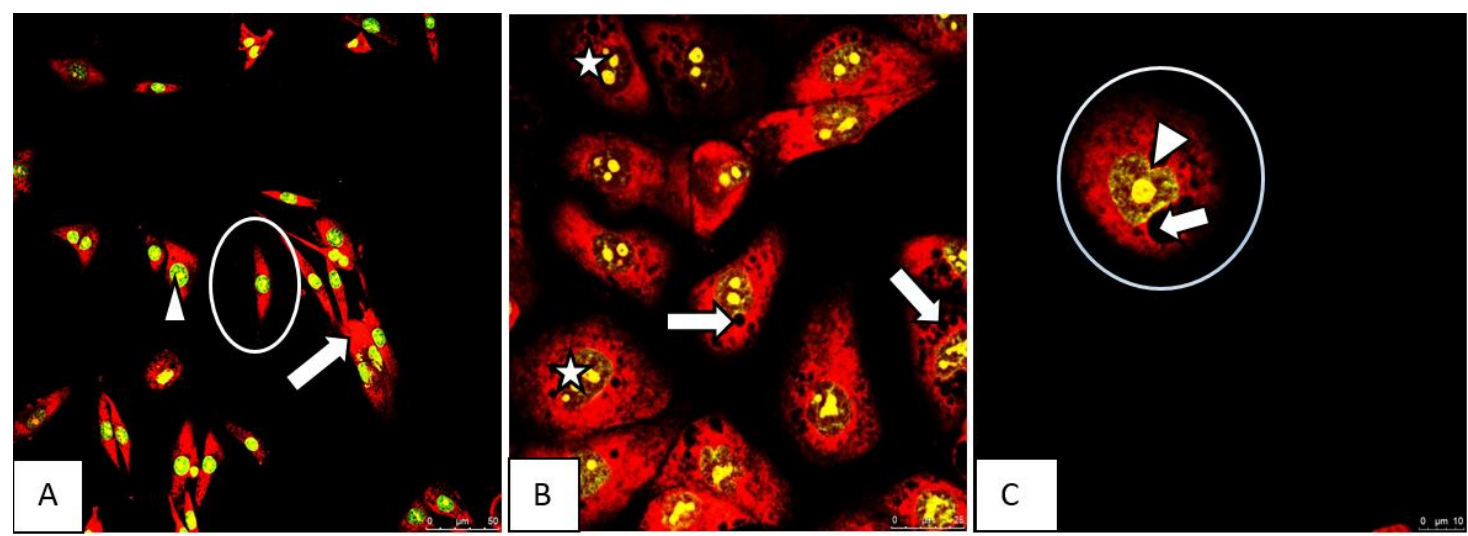

Figure3. Confocal microscopic images of HeLa control cells (A; Arrowhead-Compact nucleus, ArrowUndamaged cell morphology, Circle-Fusiform cell shape) and HeLa cells exposed to IC ${ }_{50}$ value of quercetin for 48 hours (B and C; Arrow-Hole formation on cytoskeleton, Asterisk- Fragmented and condensed nuclei, Arrowhead-Shrinkge (ondulation) on nucleus and Circle-Shrunken circular shaped cell).

Figure 3 shows confocal microscopic images of HeLa control cells and HeLa cells exposed to $\mathrm{IC}_{50}$ value of quercetin.

Morphological analysis recorded with confocal microscopy indicated to the changes at the morphology of HeLa cells that were fusiform and compact prior to the quercetin exposure (Figure 3A). The morphology of HeLa cell exposed to quercetin was found to be disintegrated and holes were found in the cytoskeleton and fragmentations and chromatin condensations were seen at confocal images of quercetin treated HeLa cells along with cell shrinkage, ondulations on nucleus and circular cell shape (Figure 3B and C). All these morphological changes were evaluated as structural signs of programmed cell death in $\mathrm{HeLa}$ cells exposed to quercetin $\mathrm{IC}_{50}$ concentration for 48 hours.

\section{Transmission Electron Microscopy Findings}

Figure 4 shows ultrastructure of HeLa control cells and HeLa cells treated with $\mathrm{IC}_{50}$ concentration of quercetin. 
The Effects of Quercetin with or Without Hyperthermia on HeLa Cells

Untreated HeLa cell's ultrastructure found to be with compact nucleus, organels like mitochondria and undamaged cell membrane (Figure $4 \mathrm{~A}$ ). Ultrastructural changes recorded on quercetin applied HeLa cells were swollen mitochondria, loss of cristae, shinkage and condensation of nucleus typically to apoptotic nuclei (Figure 4B and C). Typical apoptotic finding were recorded on quercetin applied HeLa cells for 48 hours.

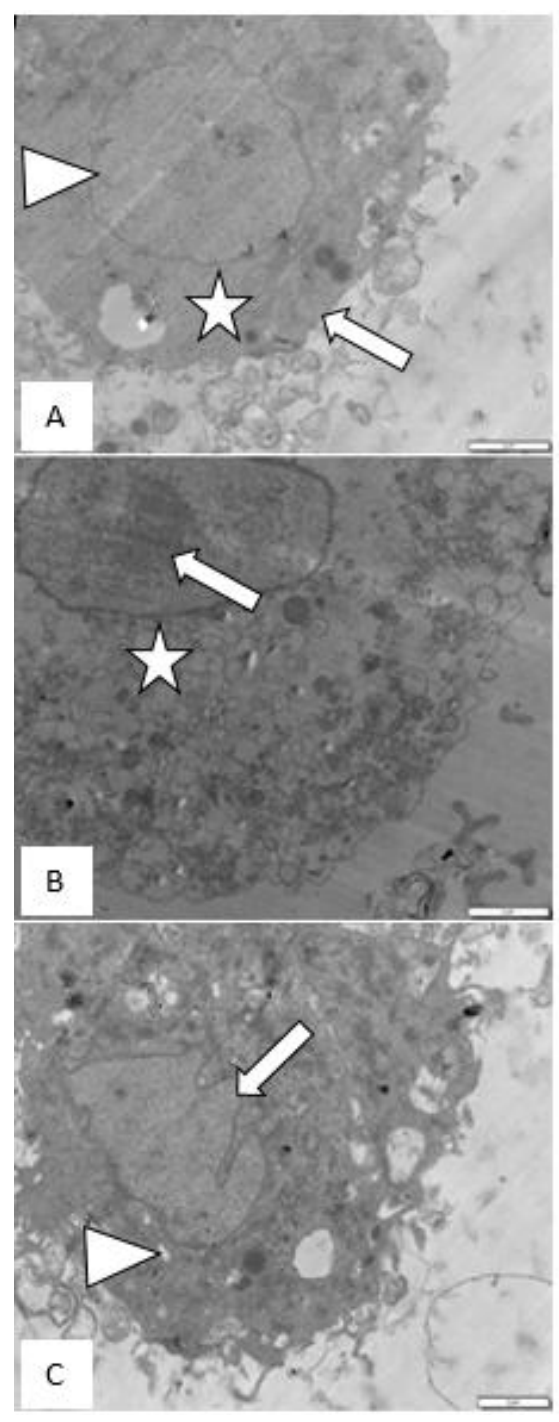

Figure4 Ultrastructure of HeLa control cells (A; Arrow-cell membrane, Asterisk-compact cytoskeleton; Arrowhead-nucleus) and HeLa cells treated with $I_{50}$ concentration of quercetin for 48 hours ( $B$ and $C$; Arrow condensed nucleus, Arrowhead-Loss of cristae, Asterisk-swollen mitochondria).

Anexin V Analysis Results
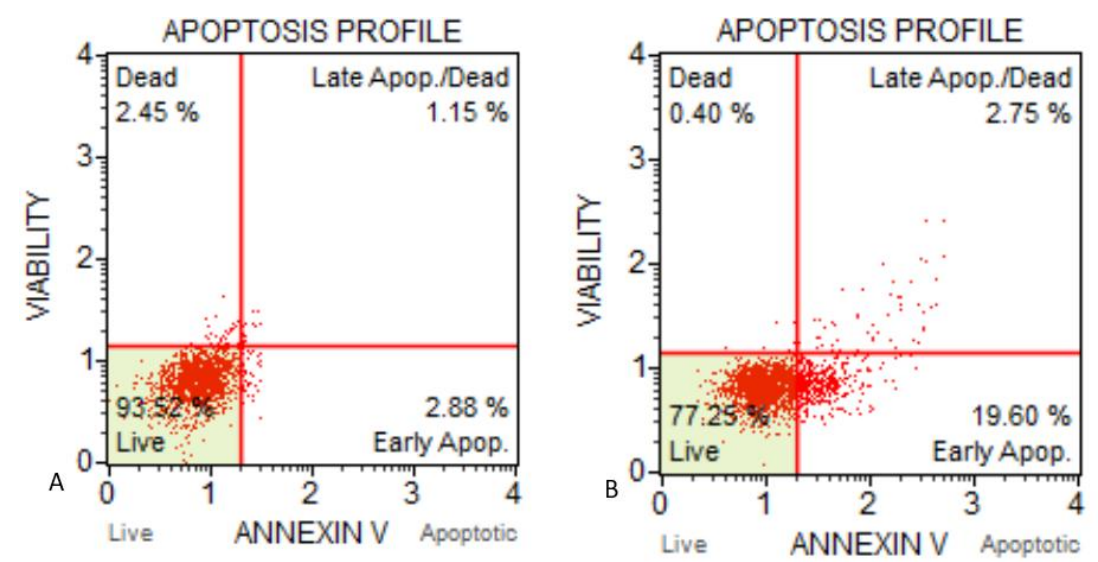

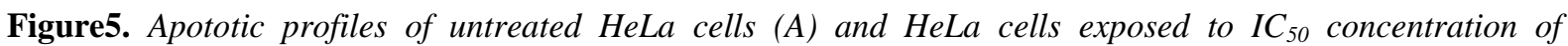
quercetin for 48 hours $(B)$. 
Figure 5 shows apototic profiles of untreated $\mathrm{HeLa}$ cells and $\mathrm{HeLa}$ cells exposed to $\mathrm{IC}_{50}$ concentration of quercetin.

Analysis of the apoptotic profiles of untreated HeLa cells showed that $93.52 \%, 2.88 \%, 1.15 \%$ and $2.45 \%$ of cell population were live, Early apoptotic, Late apoptotic and dead, respectively.

Reactive Oxygen Species Levels of HeLa cells

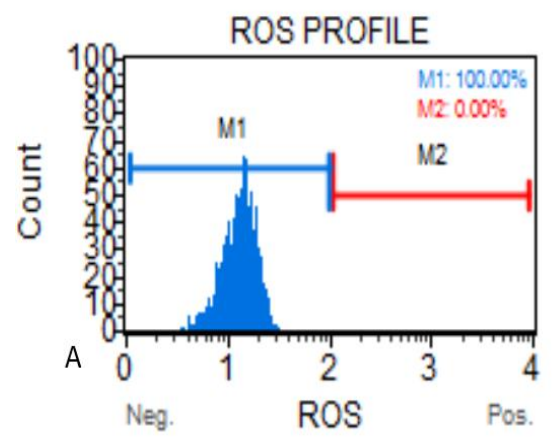

In the treated group the percentage of viable cells was decreased to 77 and early apoptotic, late apoptotic and dead cell percentages were arised to $19.6 \%, 2.75 \%$ and $0.40 \%$, respectively. With annexin $\mathrm{V}$ test results the apoptosis trigering activity of quercetin on HeLa cells after incubation period of 48 hours was showed.

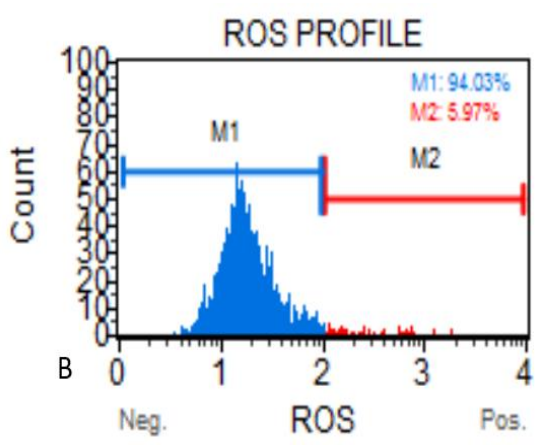

Figure6. Oxidative stress finding of HeLa control cells (A) and HeLa cells exposed to $\mathrm{IC}_{50}$ dose of quercetin for 48 hours (B). M1-ROS (-) cells and M2-ROS (+) cells.

Figure 6 shows oxidative stress finding of $\mathrm{HeLa}$ control cells and HeLa cells exposed to $\mathrm{IC}_{50}$ dose of quercetin.

The ROS profile of untreated and quercetin treated HeLa cells was evaluated flow cytometrically. With this results it was shown that the total population of tested HeLa control cells do not contain reactive oxygen species that means they are ROS (-). ROS level of quercetin treated HeLa cells was recorded to be $5.97 \%$. This slight increase of ROS level may indicate cell death mode with ROS generation but further analysis are needed to reveal the cell death mechanism of quercetin on HeLa cells.

Our findings all together underline the cytotoxic, antiproliferative and proapoptotic efficacies of quercetin on HeLa cells in dose and time depended manner. This agent may be used as additional therapy agent for cancer treatment but after deeper molecular and pharmacological investigations.

\section{DISCUSSION}

In the light of potential side effects of antineoplastic drugs, searching for natural products with minimum side effects may also be a great strategy for cervical cancer treatment. Quercetin has been proved to be a sufficient growth suppressor in a number of cell lines (14).

Various studies demostrated the mechanisms of action of quercetin on HeLa cells. The present study proved that quercetin have good anticancerous activities in a dose and timedependent manner in vitro by inhibiting the proliferation of HeLa cells. The recorded $\mathrm{IC}_{50}$ value of quercetin was $114 \mu \mathrm{M}$ for 48 hours. Wang et al. showed the quercetin induced inhibition of proliferation of HeLa cells with increasing dose-dependent manner (15). The study demostrated that the autophagy increased with the increase of quercetin concentration, and maximized at $50 \mu \mathrm{M} / 1$. Also TEM examinations revealed the autophagic vacuoles as in our study.

Bishayee et al. determined cell viability by MTT assay and $50 \%$ cell viability was achieved at $110.38 \pm 0.66 \mu \mathrm{m}$ of quercetin at 18 h.(16).

Mitochondria acts as a regulator of promoting or inhibiting programmed cell death . The loss of the mitochondrial membrane leads to an increased generation of ROS and apoptosis (17). So ROS generation is one of the important mechanisms for induction of apoptosis. It blocks the migration of cancer cells and induces cell cycle arrest (20). But in our study, ROS level of quercetin treated HeLa cells was recorded to be $5.97 \%$. As a result it showed slight increased levels of intracellular ROS formation.

In contrast Metodiewa et al. revealed the action of quercetin as a prooxidant molecule causing DNA damage and cell cycle arrest with mitochondrial apoptosis (18). The study conducted by Vidya et al, showed the induction of caspases $3 / 7$ activity by quercetin associated with apoptosis in HeLa cervical cancer cells (19). 
Quercetin usage on cancer cells varied most widely. Yang et al. examined its effect on HT29 colon cancer cells.(21) Treatment with 50, 100 or $200 \mu \mathrm{M}$ quercetin, caused chromatin condensation, nuclear collapse and apoptotic body formation in cells observed by TEM. Apoptotic cell death was also quantified by Annexin- $\mathrm{V}$, results revealed an increase in the percentage of apoptotic cells in quercetin treatment groups in a dose-dependent manner. In our study, morphological changes were also recorded by TEM in HeLa cells exposed to quercetin $\mathrm{IC}_{50}$ concentration for 48 hours. The morphology of HeLa cell exposed to quercetin was found to be disintegrated ang holes were found in the sytoskeleton and fragmentations and chromatin condensations were seen at confocal images of quercetin treated HeLa cells along with cell shrinkage, ondulations on nucleus and circular cell shape. With Annexin-V test results the apoptosis trigering activity of quercetin on HeLa cells after incubation period of 48 hours was also showed.

In order to detect the effect of temperature with quercetin application, different concentrations of quercetin were applied to HeLa cells at different temperatures. the test results put forth that temperature does not influence significantly on the growth inhibition of HeLa cells applied with quercetin. In accordance with our study, Li et al found out that the effects of hyperthermia were much more stronger on cell viability and apoptosis in a HPV-negative cell line compared to HPV-positive cell lines (22). Also Sukovas et al, scrutinized the effect of hyperthermia on OVCAR-3 cells and found out that at $42^{\circ} \mathrm{C}$ did not significantly increase the effect of cisplatin on the viability and apoptosis (23). Moreover, an antagonistic effect of hyperthermia and cisplatin was observed.

\section{CONCLUSION}

Our results demonstrated that quercetin could induce apoptosis in a time- and concentrationdependent manner in HeLa cervical cancer cells. So it could have a promising role as an effective chemotherapeutic agent against human cervical cancer.

\section{REFERENCES}

[1] Hansen JM, Coleman RL, Sood AK . Targeting the tumour microenvironment in ovarian cancer. Eur J Cancer 2016; 56: 131-43.

[2] Fitzmaurice C, Allen C, Barber RM, et al. Global, regional, and national cancer incidence, mortality, years of life lost, years lived with disability, and disability-adjusted life-years for 32 cancer groups, 1990 to 2015: a systematic analysis for the global burden of disease study. JAMA Oncol 2016; 3: 524-48.

[3] Dürst M, Gissmann L, Ikenberg H, zur Hausen H. A papillomavirus DNA from a cervical carcinoma and its prevalence in cancer biopsy samples from different geographic regions. Proc Natl Acad Sci USA 1983; 80: 3812-15..

[4] Martinez-Zapien D, Ruiz F, Poirson J, et al. Structure of the E6/E6AP/p53 complex required for HPV-mediated degradation of p53. Nature 2016; 529: 541-45.

[5] Chen J: The cell-cycle arrest and apoptotic functions of p53 in tumor initiation and progression. Cold Spring Harb Perspect Med 2016; 6:a026104.

[6] Waggoner SE. Cervical cancer. Lancet Oncol 2003; 361: 2217-25.

[7] Haverkos H, Rohrer M, Pickworth W. The cause of invasive cervical cancer could be multifactorial. Biomed Pharmacother 2006; 54: 54-9.

[8] Gupta S, Afaq F, Mukhtar H. Selective growthinhibitory, cell-cycle deregulatory and apoptotic response of apigenin in normal versus human prostate carcinoma cells. Biochem Biophys Res Commun 2001; 287: 914-20.

[9] Devi KP, Rajavel T, Habtemariam S, Nabavi SF, Nabavi SM. Molecular mechanisms underlying anticancer effects of myricetin. Life Sci 2015; 142: 19-25.

[10] Dewanjee S, Joardar S, Bhattacharjee N, et al. Edible leaf extract of Ipomoea aquatica Forssk. (Convolvulaceae) attenuates doxorubicininduced liver injury via inhibiting oxidative impairment, MAPK activation and intrinsic pathway of apoptosis. Food Chem. Toxicol 2017; 105: 322-36.

[11] Hollman PCH, Katan MB. Dietary flavonoids: intake, health effects and bioavailability. Food Chem Toxicol 1999; 37: 937-42.

[12] Tanigawa S, Fujii M, Hou DX. Stabilization of p53 is involved in quercetin-induced cell cycle arrest and apoptosis in HepG2 cells. Biosci Biotechnol Biochem 2008; 72: 797-804.

[13] Thangasamy T, Sittadjody S, Lanza-Jacoby S, Wachsberger PR, Limesand KH, Burd R. Quercetin selectively inhibits bioreduction and enhances apoptosis in melanoma cells that overexpress tyrosinase. Nutr Cancer 2007; 59: 258-68.

[14] Kim SH, Choi KC. Anti-cancer effect and underlying mechanism(s) of kaempferol, a phytoestrogen, on the regulation of apoptosis in diverse cancer cell models. Toxicol Res 2013; 29: 229-34.

[15] Wang Y, Zhang Wei, Lv Q, Zhang J, Zhu D. The critical role of quercetin in autophagy and apoptosis in HeLa cells. Tumour biology 2015; 37: 925-29. 
[16] Bishayee K, Ghosh S, Mukherjee A, et al. Quercetin induces cytochrome-c release and ROS accumulation to promote apoptosis and arrest the cell cycle in $\mathrm{G} 2 / \mathrm{M}$, in cervical carcinoma: signal cascade and drug-DNA interaction. Cell Proliferation 2013; 46:153-63.

[17] Na AR, Chung YM, Lee SB, Park SH, Lee MS, Yoo YD. A critical role for Romo1-derived ROS in cell proliferation. Biochem Bioph Res Co 2008; 369: 672-78,

[18] Metodiewa D, Jaiswal AK, Cenas N, Dickancaité E, Segura-Aguilar J. Quercetin may act as a cytotoxic prooxidant after its metabolic activation to semiquinone and quinoidal product. Free Radic Biol Med 1999; 26: 107-116.

[19] Vidya Priyadarsini R, Senthil Murugan R, Maitreyi S, Ramalingam K, Karunagaran D, Nagini S. The flavonoid quercetin induces cell cycle arrest and mitochondria-mediated apoptosis in human cervical cancer (HeLa) cells through p53 induction and NF- $\mathrm{B}$ inhibition. Eur J Pharmacol 2010; 649: 84-91.

[20] Droge W: Free radicals in the physiological control of cell function. Physiol Rev 2002; 82: 47-95.

[21] Yang L, Liu Y, Wang M, Qian Y, Dong X, Gu H et al.: Quercetin-induced apoptosis of HT29 colon cancer cells via inhibition of the AktCSN6-Myc signaling axis. Molecular Medicine Reports 2016; 14: 4559-66.

[22] Li Z, Wang H, Yang Y et al. Susceptibility of epithelial tumour cell lines to hyperthermia. Eur J Dermatol 2018; 28: 606-12.

[23] Sukovas A, Cesna V, Jasukaitiene A, Barauskas G, Nadisauskiene RJ, Dambrauskas $Z$ et al.: Response of OVCAR-3 Cells to Cisplatin and Hyperthermia: Does Hyperthermia Really Matter? Anticancer Res 2017; 37: 5011-18.

Citation: Ceren Ylldiz Eren et.al, "The Effects of Quercetin with or Without Hyperthermia on HeLa Cells", International Journal of Research Studies in Medical and Health Sciences. 2021; 6(1): 25-32. DOI: https://doi.org/10.22259/ijrsmhs.0601005

Copyright: (C) 2021 Ceren Yulduz Eren et.al, This is an open-access article distributed under the terms of the Creative Commons Attribution License, which permits unrestricted use, distribution, and reproduction in any medium, provided the original author and source are credited. 